\title{
Analysis Of Error Using Simple Past Tense on Recount Text Class VIII B Students of Smp Pelita Ngabang in Academic Year 2019/2020 Landak District
}

\author{
Nopinawati ${ }^{1}$ Tuminah $^{2}$ Yustina Selong ${ }^{3}$ Noor Faridha ${ }^{4}$ \\ 1. English Language Education Department, Pamane Talino Teaching College \\ Nopinawati93@gmail.com \\ mona.condro@gmail.com \\ yustinaselong7@gmail.com \\ 4. English Language Education Department, Universitas Mochammad Sroedji Jember \\ Noorfaridha26@gmail.com
}

\begin{abstract}
This research aims at investigating the errors using simple past tense that is often done by students in the activity of writing sentences in simple past tense on the recount text of class VIII B of junior high school PELITA Ngabang in academic year 2019/2020 Landak Regency. The study uses a qualitative research design. The research was carried out at junior high school PELITA Ngabang on November 22nd, 2019. The research subjects were VIII B amount of 20 students. After analyzing the errors of the 20 past form in the recount texts that were finished by 20 students there were 73 errors. Finally, the authors concluded that the past form errors in the recount text were the types of errors omissions, $19,17 \%$, type of errors addition $26,02 \%$, types of errors misformation $27,39 \%$, types of errors misordering $27,39 \%$.
\end{abstract}

\section{Keywords: error analysis, simple past tense, recount text.}

\section{INTRODUCTION}

English is an international language that is used to communicate both verbally and in writing, to master English well, it must master four basic skills that must be mastered, namely: writing skills, reading skills, speaking skills, and listening skills. When students carry out English learning often found various errors both writing (reading), reading (reading), speaking (speaking), as well as in listening or listening (listening) made by students. Errors in the use or use of foreign languages are called errors. These errors Often occur in people who use languages that are not native speakers of that language. Many errors are caused due to a lack of knowledge and understanding of foreign languages used as the target language. When students learn to write English, they will be confronted with tense and grammar. These two things cannot be separated from learning English writing skills. In English, there are 16 tenses known. Simple past tense is a tense pattern in English that is used for events that occurred in the past. When writing recount text, students need a good simple past tense foundation because this simple past tense will be applied and used when a student writes the recount text. In simple past tense sentences there are changes in verbs that are used to explain that an event occurred in the past. If students cannot use tenses properly and correctly, students will make the wrong sentences. Many students find errors in the use of tenses because students lack the mastering of tenses, especially the difference between regular verbs and irregular verbs. Regular verb uses the second verb (verb II) and irregular verb uses auxiliary verbs "was" and "were", as well as time information, among others (yesterday, one day, once upon a time, etc.). Therefore, error analysis has an important role to know what types of mistakes are most often done by students, to find out the causes of errors and how students learn from their mistakes.

\section{Error Analysis}

a.Interference in Error Analysis

Language errors are a form of process to find errors in the use of language forms. The understanding of error analysis presented by Mubasyira (2017, p. 71) language error analysis is a 
form of process to find errors in the use of language forms that aim to obtain information data that can be used to conclude the teaching and learning process of language. Language errors occur because of the use of forms of language (speech or writing) that deviate from the standard language rules. According to Pranowo in Susilawati and Sulhan (2018, p.68) "Language errors are deviations from the rules of language use" language errors usually done by second language or foreign language learners. Several types of errors, namely errors in omission, misformation, and misordering. According to Ellis in Irawan (2018, p. 93), there were some mistakes made by students in learning simple past tense, including omission, misformation, and misordering.

\section{a. Factors Causes Language Mistakes}

According to Tarigan in Mubasyira (2017, p. 71), language errors are as follows:

\section{1) Interlanguage Errors}

Errors caused by the mother tongue interference of students towards the second language learned.

\section{2) Intralanguage Errors}

According to Richard in Mubasyira (2017, p. 71) states that the intrude error factor is caused by:

a) Over-generalization Includes instances where a student creates a distorted structure based on his experience of other structures in the target language.

Example: He can sing, it should be He can sing, We are hope, it should be we should hope.

b) Ignorance of rules restrictions. Includes the application of rules to contexts that do not accept the application.

Example: The man whom I saw him, We saw him played football and we admired it.

c) Application of imperfect rules. This occurs because of a general deviation of structure that ignores the development of rules to produce acceptable or acceptable sentences. Example: a teacher asks "Do you read much?" student answers, "Yes, I read much"

d) Incorrectly hypothesizing false concepts. This happens because of a misunderstanding of the differences in the target language. Example: They have opened the door, We are walking to school every day.

a. Types of Language Mistakes

According to Krashen's in Puspita Sari and Yustina Dwi Putri (2016, p. 24-25) suggested that the taxonomy of surface structures is divided into four general categories with sub-categories, namely:

\section{1) Omission}

An omission is characterized by the loss of something that should be raised in the form of correct speech. Example: error due to commission (You are a good student), correct sentence (you are a good student)

\section{2) Addition}

The addition is the opposite of omission. It is characterized by the presence of something that should not be present in a properly arranged speech. There are 3 types of errors in Additions, namely: Double Marking, Regularization, and Simple addition.

According to Mubasyira (2017, p. 72) describing Double Marking (double markers), Regularization, and Simple addition:

a) Double marking, which is an elemental error that is stated twice when a language requires only one expression. Example: Mats didn't eat bread, Mats should not eat bread.

b) Regularization i.e. errors of applying regular or regular rules. Example: Sing becomes singed, Come becomes comed.

c) Simple addition (simple addition), i.e. the misuse of an element that is not in the correct utterance. Example: The cows don't live in the water, The cows shouldn't live in the water.

\section{1) Misformation}

Misformation, characterized by the use of forms that are not acceptable morphemes or sentences. In this error formation, learners include something even if what is included is wrong. There are three forms of misformation, namely:

a) Regularization error, for example: runned should be run, sheeps should be sheep.

b) Archives, for example, that cats should be those cats

c) Alternating Forms, for example, I saw you yesterday and he would have seen them.

\section{2) Misordering}

Misordering, namely the placement of morphemes or a collection of morphemes that are not right on the utterance. Example: error due to misordering: I do not know who is he, correct sentence: I do not know who he is.

a. Language Error Analysis Procedure

According to Tarigan in Indihadi (2013, p. 26) procedures for analyzing language errors as follows: 
Simple addition i.e. the misuse of an element that is not in the correct utterance. Example: The cows don't live in the water, The cows shouldn't live in the water.

Misordering, namely the placement of morphemes or a collection of morphemes that are not right on the utterance Example: error due to misordering: I do not know who is he, correct sentence: I do not know who he is.

a. Language Error Analysis Procedure

According to Tarigan in Indihadi (2013, p. 26) procedures for analyzing language errors as follows:

\section{1) Collecting data}

Language errors were obtained from students' written test results and language errors made by students were collected in the form of tests.

2) Identifying mistakes based on language level for example; error Omission (removal), Addition (addition), misformation (wrong formation).

3) Ranking or ranking errors.

Sorting errors based on the frequency of errors.

4) Explain the situation.

Explain what is wrong, the cause of the error, and how to correct the error.

5) Predicting linguistic levels that are prone to error. Estimating the level of language learned by students who have the potential to make mistakes.

6) Correcting errors.

There are many ways of correcting errors as making the good components of the language teaching and learning process such as objectives, materials, methods, media, and assessment.

Purpose of Error Analysis

Error Analysis has a very important purpose to do or do. According to Corder in Indihadi (2013, p. 25), those language mistakes are not merely to be avoided, but rather phenomena that can be learned. Therefore, language error analysis has a noble purpose, including:

1) As feedback for teachers in determining goals, teaching materials, teaching procedures, and assessments that have been carried out.

2) As evidence for researchers (research) in knowing children (students) acquire and learn languages.

3) As input determination of resources or level of elements of language errors in the process of language acquisition and learning.

b. Benefits of Error Analysis
Errors indicate the level of progress of the process of acquiring a second language several benefits can be felt from an error analysis, these benefits are important, because:

1) Reflect on the role of error analysis;

2) Provide appeal to second/foreign language researchers;

Describe the process of acquiring a second/foreign language.

\section{a.Simple Past Tense Verb Form}

The forms of verbs in the simple past tense are regular verbs and irregular verbs. Regular verb uses the second verb (verb II) and irregular verb uses the auxiliary verbs "was" and "were", as well as the description of time among others (yesterday, one day, once upon a time, and so on).

b.To Be / Was-Were Placement Rules in Past Tense The setting rule to be / was-were in simple past tense there are transitive and intransitive verbs. According to Cyssco (2003, p. 125) if in a simple past tense sentence there is a verb, either a transitive verb or an intransitive verb then we should not use to be / waswere. In positive sentences, we must use past form verbs (past form), while negative sentences and interrogative sentences are formed using the auxiliary words did.

\section{Recount Text}

a.Understanding of Recount Text

That tells events that have happened before. According to Sahadadi Mulyana (2019, p. 17) recount in terminology means "retell", the target recount depends on the purpose of the person telling the event. Some examples of the purpose of the recount text are to entertain or inform the reader about events that have occurred. The recount text also aims to recount experiences that have occurred. From the description above, the researchers can be concluded that events or experiences in the past. The purpose of the text is to provide information or to entertain the reader so that there is no conflict.

b.Kinds of Recount Text

Recount text entertains or informs readers about events that have occurred there are 3 kinds of recount texts according to Mulyana (2019, p. 17):

a. Recount Text Structure

The generic structure is orientation, events, and reorientation according to Mulyana (2019, p. 17-18) Generic structure of recount text is:

1) Orientation

Gives information about the setting of the story who is involved in the story, when the event occurred, 
where the event occurred, and what happened at that time.

\section{2) Events}

The sequence of events that occur chronologically (in order of time).

\section{3) Reorientation}

Closing story or ending. The closing story can be a personal comment about the event being told.

b. Language Features Recount Text According to Mulyana (2019, p. 18-19) linguistic elements used in the recount text are:

1) Using the past form because the story event happened in the past.

2) Used personal participant, such as I, my group, etc;

3) Using action verbs (material processes), such as look, go, change.

Using linking verbs, such as was, were, saw, heard.

Using adjectives or information to specify people, animals, places, or actions.

6) Using conjunction and time connectives concerning time, such as then, first, etc.text personal recount element of the language of the personal recount text.

\section{RESEARCH METHOD}

This research used descriptive qualitative. According to Maolani (2015, p. 72), descriptive research is an activity that aims to describe a situation or phenomenon, which is designed to obtain information in its current state. Descriptive research is also carried out to illustrate the broad objectives of science, usually to develop knowledge that underlies problems and explanations. Descriptive research is also used for problems in the form of current facts of a population. The aim is to test the hypothesis of the subject being examined. Thus the researcher can conclude descriptive-qualitative is research that aims to describe a situation or phenomenon, which is designed to obtain information in the current state is used to examine the condition of natural objects.

\section{RESEARCH RESULTS}

To find out how many students make mistakes in writing simple past tense on each type of error, a classification table is used. The following table classifies the type of error.

Table 4.1 classification of error types

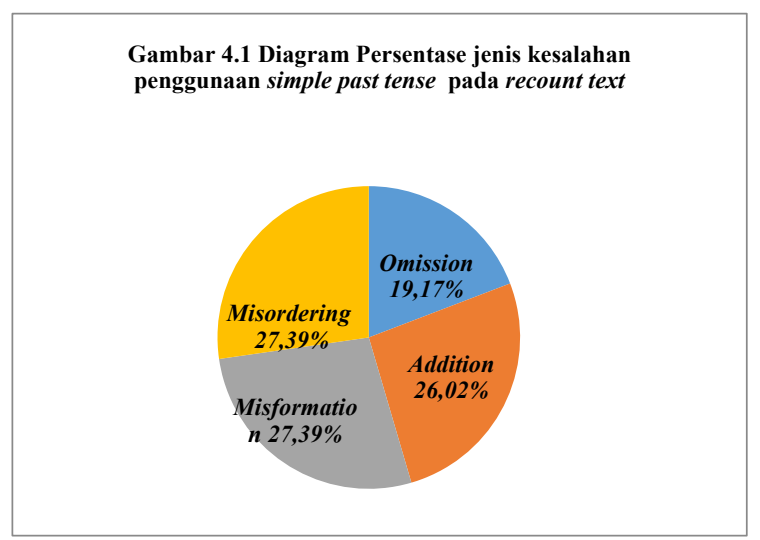

From the percentage of data analysis count of each type of error, the percentage can be explained in the diagram of the type of simple past form usage in the recount text of grade VIII B students at Pelita Ngabang Middle School as follows:

Based on the percentage diagram of the types of errors, it is evident that in the written test results of Grade VIII B students at Pelita Ngabang Middle School there are types of errors in the use of simple past tense on the recount text. The biggest type of error is misformation and misordering because the total of these types of errors together amounted to $27.39 \%$ of errors. Then the smallest type of error is omission with $19.17 \%$ of errors.

\section{CONCLUSIONS}

Based on data analysis and discussion of research results, it can be concluded in general that the majority of students of class VIII B of Pelita Ngabang Middle School still do not master the use of simple past tense in the recount text, as evidenced by the results of the analysis of each type of error. From the results and data analysis and discussion of the results of the VIII B students of Pelita Ngabang Middle School there are types of errors in using the simple past form in the recount text as follows:

a. This type of omission (omission) there are 19, $17 \%$ of errors. In the type of omission, student error cannot place ed-edged on the second form of the verb (verb II), this is due to the lack of understanding of the students in correcting ed-ed on the second form of the verb (verb II). 
b. The type of addition error (addition) there are $26.02 \%$ errors. In the type of addition error, the student's error cannot determine double addition, simple addition, and plural form regulation. This happens due to the lack of students' understanding of the addition of double like students writing eaten which is eat, students' lack of understanding in simple addition of students writing didn't but don't, students' lack of understanding of the regulation of plural students writing man and should. Type of misformation $27,39 \%$ error. In the type of formation errors (misformation), student errors in the use of regular verb and irregular verb forms. This is caused by the lack of carefulness of students in learning the forms of verbs and irregular verbs.

c. Types of misordering $27,39 \%$ errors. In the type of misordering (misordering), students' mistakes cannot be used to arrange sentences in the form of simple past tense on the recount text. This is due to the lack of student understanding in composing simple past tense sentences.

\section{REFERENCES}

Arikunto, Suharsini. (2010). Prosedur Penelitian Suatu Pendekatan Praktik. Jakarta: Rineka Cipta.

Anjarsari N, Sarwiji S, dan Slamet M. (2013). Analisis Kesalahan Pemakaian Bahasa Indonesia dalam Karangan Mahasiswa Penutur Bahasa Asing di Universitas Sebelas Maret. Analisis Kesalahan Berbahasa: BASASTRA Jurnal Penelitian Bahasa. Sastra Indonesia dan Pengajarannya Volume 2 Nomor, ISSN I230-6405.

Cyssco, Dhanny R. (2003). Mastering Tenses \& Daily Conversation. Jakarta: Puspa Swara.

Indihadi, Dian. (2013). Analisis Kesalahan Berbahasa. E-book.

Irawan, Dede. (2018). Analisa Kesalahan dalam Penggunaan Simple Past Tense Oleh Mahasiswa Semester I Program Pendidikan Bahasa Inggris. FaktorJurnal IlmiahKependidikan Vol. 5 No.ISSN 220I36054.

Iswari F, Fauzi R, Puri K. (2018). Analisis Kesalahan Penggunaan Simple Past Tense Pada Kegiatan Menulis Recount Text Mahasiswa Dkv Unindra. El-Banar: Jurnal Pendidikan dan Pengajaran ISSN: 2654-7198 Volume 02, Nomor 01, e-ISSN: 2654-5349.

Jihad A, Abdul H. (2008). Evaluasi Pembelajaran. Jakarta: Multi Pressindo.

Lado,M. J. (2007) Complete English Grammar. Jakarta: titik terang.
Maolani R, Ucu C. (2015). Metode Penelitian Pendidikan. Jakarta: Rajagrafindo persada.

Mubasyira,Mu'thia. (2017). Analisa Kesalahan Penggunaan Simple Past Tense pada English Narrative Composition Smpn 1 Bojong Gede:Jurnal Dimensi Pendidikan dan PembelajaranVol. 5 No. 2. ISSN:220176405.

Mulyana, Sahadadi. (2019). Teks Recount. Jakarta: Tim Desain Grafis.

Riduwan. (2003). Dasar-Dasar Statistik. Bandung: Alfabeta, cv.

Riduwan. (2014). Metode dan Teknik Menyusun Proposal Penelitian. Bandung: Alfabeta, cv.

Sari P, Yustina D P. (2016). Menemukan Kesalahan Gramatika dalam Esai Mahasiswa Bahasa Inggris dan Solusi Menghindarinya Univeritas Widyatarna Bandung Indonesia. Jurnal Bahasa Inggris Terapan Vol 2 Nomor. 2. ISSN:302I2-4056.Siregar, Syofian. (2014). Statistika Deskriftif untuk Penelitian. Jakarta: Rajawali Pers.

Siregar, syofian. (2014). Statistik Parametik. Jakarta: Bumi Aksara.

Sudjana, Nana. (1989). Penilaian Hasil Proses Belajar Mengajar. Bandung: Remaja Rosdakarya.

Sugiyono. (2017). Metode Penelitian Kuantitatif, Kualitatif, dan R\&D:Bandung. ALFABETA.

Susilawati, Muhammad, Sulhan. (2018). Analisis Kesalahan Penggunaan Kata Kerja Beraturan dan Tidak Beraturan pada Karangan Narasi: Jurnal DEIKSIS Vol. 10 No. p-ISSN: 2085-2274, e-ISSN 2502$227 \mathrm{X}$. 